\title{
THE CHANGE OF NATURAL LANDSCAPE IN LITHUANIA
}

\author{
*Giedrè Ivavičiūtė \\ Vytautas Magnus University, Lithuania \\ Kaunas Forestry and Environmental Engineering University of Applied Sciences, Lithuania \\ Klaipeda State University of Applied Sciences, Lithuania \\ *Corresponding author's email: ivavice@gmail.com
}

\begin{abstract}
The purpose of this article is to carry out an analysis of the natural landscape of the Republic of Lithuania in 2004-2019. During the preparation of the article, the following scientific methods were used: literature analysis, determination and evaluation of the current situation, grouping method, comparison method, graphical method, analytical and statistical analysis methods, logical analysis.

The article analyzes the change of the area of natural (natural, subnatural) landscape components (natural forests, wetlands, water bodies) during the period between the years 2004 and 2019.

The analysis showed that the two components of the natural landscape of the Republic of Lithuania during 2004-2019 increased: the forest area $(132,849.03$ ha or $6.15 \%)$ and water bodies (3,668.49 ha or 1.38\%). Unfortunately, the area of wetlands has decreased by 50,990.20 ha (35.05\%).

During the analyzed period, the natural landscape of Lithuania increased by 85527.97 ha or 3.39\%.

At present, it is particularly important to care for and restore valuable landscape complexes to fulfill their ecosystem functions. One of the most important challenges is to reconcile urbanization and nature conservation so as not to reduce significant areas of the country's natural landscape.

Key words: natural landscape, components, change of landscape.
\end{abstract}

\section{Introduction}

Landscape proposes a complex of shaping and understanding environments and landscapes (Steiner, 2011).

A harmonious landscape is a normative conception. It admits that landscape functions are the basis for solution to difficulty of human welfare.

The long-lasting landscape is surrounded in the context of regional or local landscapes. The resolution to adjust the use of a district landscape may have effects for the coherence of landscape (Opdam et al., 2018).

Landscape is seen as a fast-moving combination between cultural and natural environment. It is the aspect of coherent people viewpoints towards occupied land. Landscape has a distinctive history, which is part of their sameness (Antrop, 2000).

A regional landscape is a compound ecological and social system consisting of a fast-moving mosaic of land use.

Management demands a comprehension of the reacting human and natural processes working on the landscape over a continuity of spatial and secular scales (Parrot \& Meyer, 2012).

Currently, about $50 \%$ of the earth's ice - free land has been rearranged, and fundamentally all land has been influenced by climate change, integrated landscapes, etc. (Turner II, Lambin \& Reenberg, 2007).

Land-use change shoves biodiversity into human changed landscapes, where local ecosystems are enclosed by human induced land covers. As a result of land - use change, a rising number of species is being 'made' to occupy human - changed landscapes, which are mosaic of various land covers (Galan-Acedo et al., 2019).
Analysis of land use change has been a prevalent method concentrating on specific difficulties involved with human - environment collaboration including changes of land - use activity and land cover (for example, deforestation), reactions to climate change and effects of diverse environmental changes on forestry, agriculture, ecosystem functioning, etc. (Robinson \& Carson, 2013).

Article relevance. Landscape specialists apply an integrative outlook to comprehend various natural and human - caused drivers of landscape change acting meantime and interactively, frequently focused on connected natural systems and human (Mayer et al., 2016).

Exceptional changes to worldwide ecological systems have led to paying attention to practical methods to maintain the ecological sustainability of a speedily changing Earth (Raymond \& Cleary, 2013).

The biggest difficulty of landscape ecology in the coming years will be to force sustainability science and design to enhance education and development innovativeness about culture of landscapes and ecology, the fundamental of landscape sustainability (Musacchio, 2011).

Knowing how landscape aspects influence biodiversity models and ecological procedures at landscape and local scales is critical for extenuating consequences of worldwide environmental change (Tshamtke et al., 2012).

The object of article is the natural landscape of Lithuania.

The aim is to carry out a research of the changes in the natural landscape of Lithuania during the years 2004-2019. 
Tasks to be resolved:

1. To characterize the present state of the natural landscape of Lithuania.

2. To research the components of natural landscape of the Republic of Lithuania and their changes.

3. To investigate the changes of natural landscape area in the Republic of Lithuania during the years 2004-2019.

\section{Materials and Methods}

Analytical, statistical, logical and comparative analysis methods were used for the investigation.

In order to determine the change of the natural landscape area, the data of the Land Fund of the Republic of Lithuania for 2004-2019 was analyzed.

During the research, the current situation of the Lithuanian natural landscape was analyzed. The condition of the components of the natural landscape is presented.

The clustering method was used in this article. Lithuania's natural landscape is divided into natural components: forests, water bodies and wetlands.

The paper deals with the change of the area of these components between the years 2004-2019. Changes in the natural landscape area over a period of 15 years were also analyzed.

The method of logical analysis was used to determine the causes of the changes of landscape components as well as the changes in the natural landscape.

The land fund statistics of Lithuania, graphically shown in figures, were used for the implementation of the analysis of natural landscape change of the Republic of Lithuania during the years 2004-2019. Statistics were analyzed, processed and presented in 10 figures.

Also, there is foreign and Lithuanian literature and research analysis presented in scientific publications or journals.

\section{Results and Discussion}

Research of the present status.

Natural (natural, subnatural) landscape is a landscape formed and still under the influence of natural processes, for the development of which natural processes have an essential influence, and human activities have a minimal influence (relatively natural forests, wetlands, water bodies preserved) (Lietuvos, 2004).

The landscape of Lithuania is a mosaic territorial and spatial structure created by the natural factors that have occurred since the last glacial period and the human economic activity that started 4-5 thousand years ago. Analyzing the natural features of the Lithuanian landscape (Basalykas, 2014), it was found that the country is dominated by clayey plains (55.2\% of the territory).

Lithuania is dominated by rustic landscape (covers about $75 \%$ of Lithuania territory). Larger areas of the natural landscape are preserved in the eastern and southeastern part of the country, in the western part of the Samogitian Heights, in the areas of the great deltas and do not exceed $15 \%$ of the territory of Lithuania. About $10 \%$ of the territory is occupied by a rapidly expanding urban, urbanized landscape.

In Lithuania, natural frame areas cover about 60$65 \%$ of the country's area. This corresponds to a geoecologically optimal proportion between areas that are heavily used and nature-sustaining.

The share of natural frame areas in individual municipalities varies, for example, in Joniškis, Pakruojis, Pasvalys municipalities it is $35-40 \%$, Varèna, Zarasai - up to $75-80 \%$ of their total area. Most of the district municipalities have 55 to $65 \%$ of their area covered by natural frame. The ecological optimization of natural frame areas is inevitably linked to the increase of the total forest cover of the country.

Protected territories are an important part of the natural landscape; therefore, these protected areas so important for the landscape and the environment have been established in Lithuania for the preservation of nature and values. There are 6 state parks in the country, which cover $0.29 \%$ of Lithuania, 514 reserves, occupying $2.42 \%$, and 684 state protected natural heritage objects. There are 3 restoration sites in the country, 35 state parks, which make up $9.08 \%$ of the country’s territory, 32 biosphere polygons (3.62\%) and 566 Natura 2000 sites (1.94\%).

The high level of modern anthropogenic impact on nature in terms of farmland uptake, urbanization, environmental pollution, nature recreation and other economic and non-economic interventions threatens the maintenance of any natural ecosystem.

The landscape must be shaped as a whole, i.e. as a natural and urban complex where the balance between the natural, anthropogenic and anthropogenic landscape is very important.

Changes in the components of the natural landscape.

The natural landscape consists of the following natural components: forests, water bodies and wetlands.

Forests. In Lithuania forest area covers 33.07\%. As stated by the data of 2019, forest area covers 2,158,949.68 ha.

After examination of the present status of the forests in Lithuania, it has been confirmed that the forested counties are Alytus (48.28\%), Vilnius (42.91\%) and Telšiai (35.83\%) (Figure 1).

It has been established that the least forested is Marijampolè county (21.50\%). 
In Lithuania, coniferous species make up 56.20\%, pine forests predominate here (35.40\%) (Figure 2) (Ivaviciute, 2018).

In 2004, forests covered an area of 2,026,100.00 ha in the country. Between 2004-2019 the forest area increased by 132,849.03 ha (6.15\%) (Figure 3).

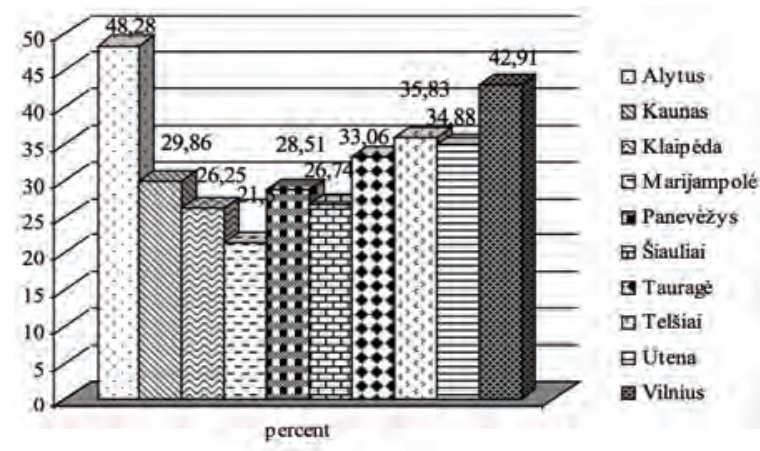

Figure 1. Forest coverage in counties in percentages in 2019.

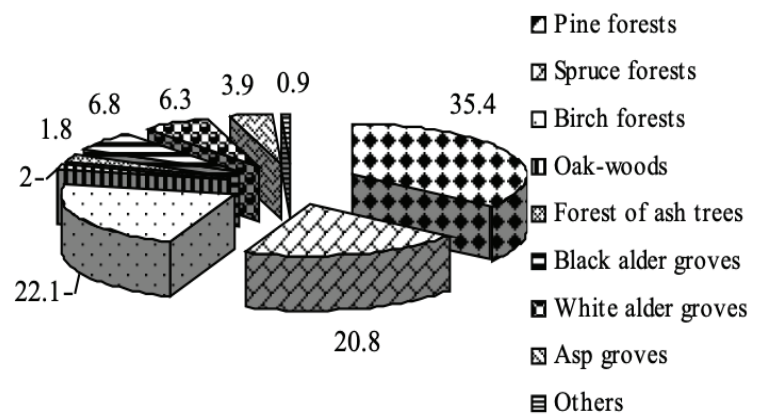

Figure 2. The main types of forest trees in percentage.

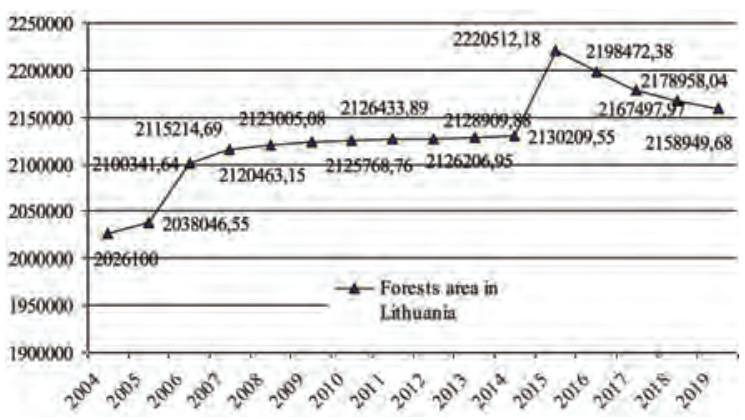

Figure 3. Forest area change in Lithuania in 2004-2019 (Nacionaline, 2004-2019).

It was determined that the forest area in Lithuania during the years 2004-2019 increased from 32.03\% to $33.07 \%$ (Figure 4).

The forest area has developed due to the enforcement of the forest development program, the stimulation of planting forests, the stimulation of forests' reclamation, participation in the Rural Development Program and etc.

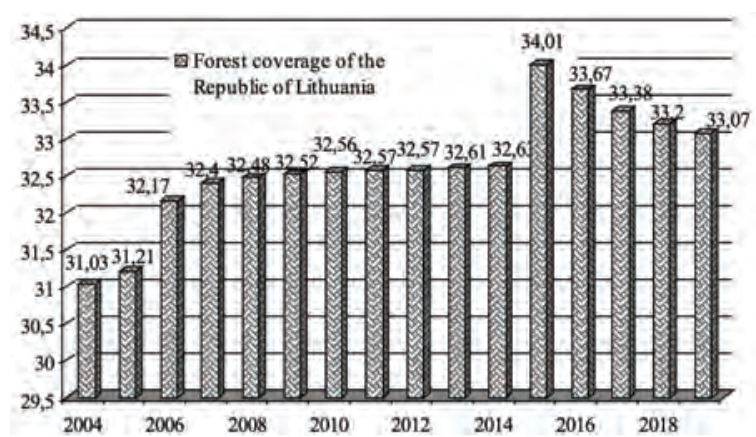

Figure 4. Forests coverage in percentages in Lithuania during the years 2004-2019 (Nacionaline, 2004-2019).

Water bodies. The entire territory of Lithuania is located in the Baltic Sea basin. The country's hydrographic network consists of rivers, channels, lakes and ponds, the coast, the Baltic Sea and artificial impassable surface water bodies (Figure 5).

According to the data of February 2018 registration of cadastral objects of rivers, lakes and ponds of Lithuania, the largest area of the territory of country is covered by lakes $-884.56 \mathrm{~km}^{2}$, Curonian Lagoon covers $413 \mathrm{~km}^{2}$, riverbeds cover $332 \mathrm{~km}^{2}$ and ponds $-236 \mathrm{~km}^{2}$.

There are 5 channels registered in Lithuania: King Wilhelm Channel, Venta overpass, Sanžilè Channel, Merkys - Vokè Channel, Pailiai Channel with a total length of 55,845 km.

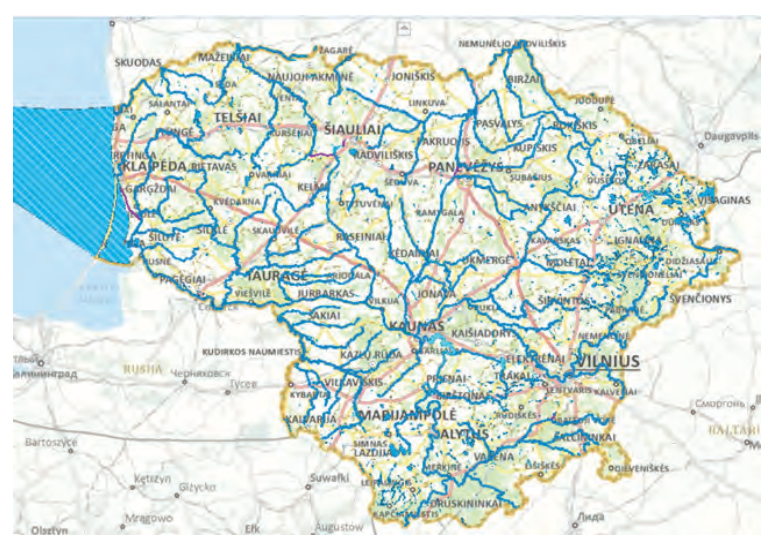

Figure 5. Map of Lithuanian Hydrographic Network (Aplinkos, 2019).

There are 2756 lakes in the country with a total area of 88456,491 ha. Of these, 31 are larger than 500 ha and 10 are larger than 1000 ha. Lithuania has 150 lakes larger than 100 ha, estimating for $65 \%$ of the lake area. The largest number of lakes is in the Baltic highlands (the lakes in Zarasai area reach $10 \%$ ), the smallest number - in the Central Lithuanian lowlands. There are 1034 ponds registered in the cadastre of rivers, lakes and ponds. Their total area is 23619,395 ha, 
of which more than 500 ha -4 and more than 1000 ha -3 . The largest lakes of the country are: Tauragnas $(62.5 \mathrm{~m})$, Malkèstaitis $(57.0 \mathrm{~m})$ and Asveja $(50.2 \mathrm{~m})$.

Lithuania has around 30000 streams and rivers, which are longer than $0.25 \mathrm{~km}$ and their absolute length is 63.70 thousand $\mathrm{km}$. The number of streams and rivers, which are longer than $3 \mathrm{~km}$ is 4418 . The number of rivers longer than $10 \mathrm{~km}$ is 816 (3\%), and more than $100 \mathrm{~km}-17$. The longest rivers in the country are Nemunas (475 km in Lithuania), Neris (234 km).

Administrative units for river basin districts are formed for the management of Lithuanian waters and water bodies: Nemunas, Venta, Lielupe and Dauguva.

In 2004, water bodies made up $4.01 \%$ of the total area of Lithuania and occupied 262,199.77 ha.

In 2019, water bodies made up $4.07 \%$ of the country territory.

The largest area of water bodies is found in Klaipeda county $(54,784.49$ ha), where water bodies make up $10.49 \%$ of the total area of the county. Water bodies are also abundant in Utena county (54026.25 ha or $7.51 \%$ ) (Figure 6).

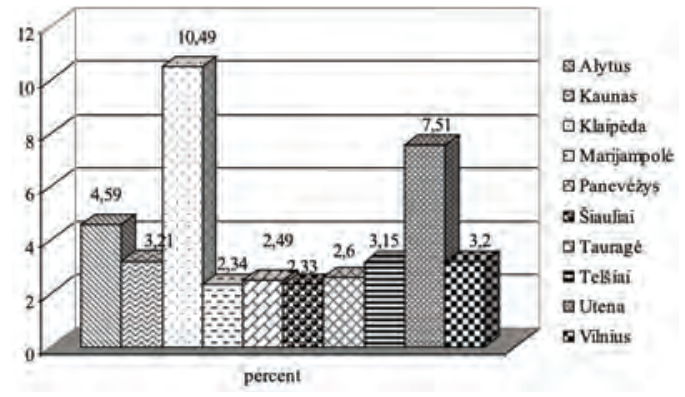

Figure 6. Water bodies coverage in counties of Lithuania in percentages in 2019.

During the interval of the years 2004-2019, the area of water bodies increased by 3,668.49 ha (1.38\%) and by 2019 occupied 265,868.26 ha (Figure 7).

The area of water bodies increased during the analyzed time due to the development of new or existing ponds for fishing and other purposes.

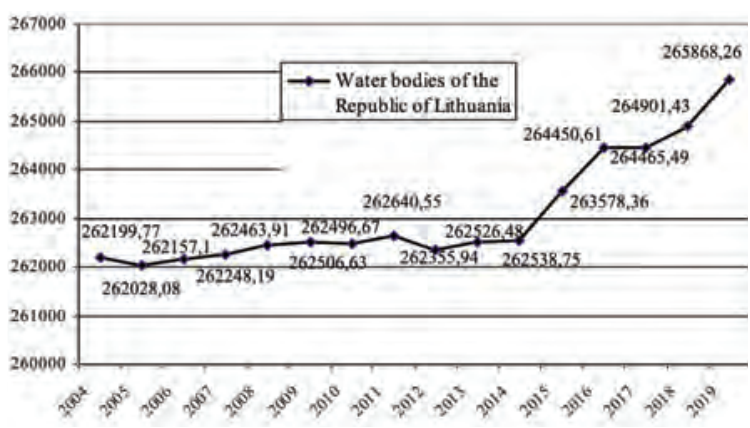

Figure 7. Water bodies change in the country between the years 2004-2019 (Nacionaline, 2004-2019).
At present, it is necessary to ensure that water bodies do not contain dangerous substances, watercourses are protected against erosion, the stability of water bodies and their coastal ecosystems is enhanced, and the coastal natural landscape and its aesthetic values are protected.

Wetlands - consistently wet areas of the earth's surface with peculiar vegetation that results in the formation of peat.

Most of Lithuania's wetlands are of lake origin. There are three types of wetlands in Lithuania: low moors, transitional moors and bogs. Most of Lithuania is dominated by low moors. They make up $71 \%$ of all wetland area. Bogs occupy $22 \%$, while transitional moors - 7\%. The Great Low Moors of Lithuania formed in the valleys of the Merkys and Voke Rivers Baltoji Voke, Naujienos, Šakos wetlands. Small marshes are common in Eastern Lithuania.

Seven Lithuanian sites have been assigned as Wetlands of International Importance: Čepkeliai, Kamanai, Viešvilè Nature Reserve and Žuvintas Biosphere Reserve, as well as Nemunas Delta Regional Park, Girutiškis Wetland and Adutiškis Svyla - Birvetai Wetlands Complex.

Analysis of wetlands in Lithuanian counties revealed that the majority of wetlands are situated in Alytus County, where wetlands make up 2.97\%, Utena (2.65\%) and Vilnius (1.97\%) counties (Figure 8).

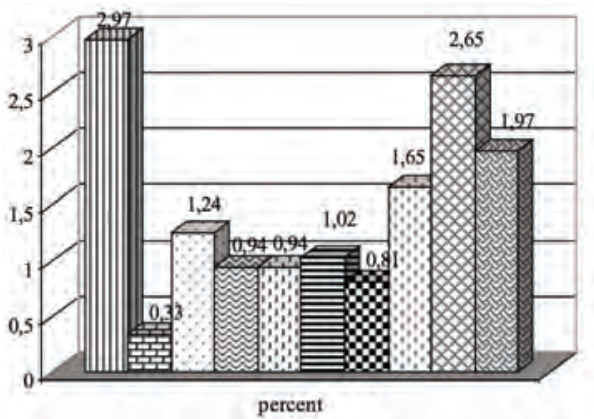

DAlytus 口 Kaunas 口Klaipèda ⿶) Marijanpolé a Panevėžys EŠiauliai Taurage 口Telsiai EUtena ৫) Vilnius

Figure 8. Wetlands area in Lithuanian counties in percentages in 2019.

Most wetlands are located in Molètai $(6.55 \%$ of municipal area), Zarasai (5.79\%) and Ignalina (4.63\%) districts. The Nemunas Delta, the Seaside Lowland are also waterlogged.

Pakruojis (2.10\%), Pasvalys (1.29\%), and Šakiai (1.28\%) areas are among the least waterlogged.

In Lithuania, wetlands made up $2.23 \%$ of country and covered 145,477.45 ha in 2004.

In 2019 , wetlands made up $1.45 \%$ of the country territory.

The area of wetlands in 2004-2019 decreased by $50,990.20$ ha (35.05\%) and covered $94,487.25$ ha in 2019 (Figure 9). 


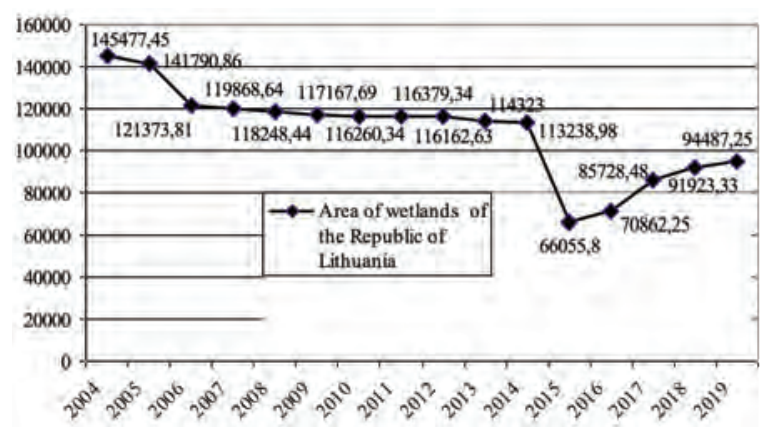

Figure 9. Wetlands area change in the country in 2004-2019 (Nacionaline, 2004-2019).

The wetland area was shrinking due to natural processes, climate change and human activities.

For humanity, understanding the key functions of wetlands, it is crucial to ensure that the use of wetlands for one's own purposes does not disturb the balance of nature, and thus the ability to survive or meet other needs.

The change of natural landscape.

The analysis shows that the components of the natural landscape of the Republic of Lithuania have changed. It has been figured out that during 2004-2019 the forest area increased by $132,849.03$ ha or $6.15 \%$, water bodies increased by $3,668.49$ ha or $1.38 \%$. Unfortunately, the area of wetlands in Lithuania decreased by 50,990.20 ha (35.05\%).

In 2019, wetlands made up the smallest part of the natural landscape (3.75\%), but forests (85.70\%) and water bodies (10.55\%) made up the largest part (Figure 10).

In 2004, the natural landscape of the country covered $37.27 \%$ of the total area of Lithuania and occupied 2,433,777.22 ha. In 2019, the natural landscape made up 38.59\%.

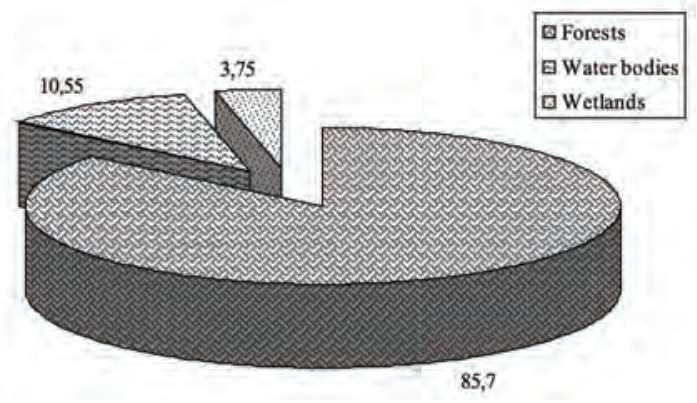

Figure 10. Percentage distribution of components of the natural landscape in 2019.
In 2004-2019, the natural landscape of Lithuania increased by 85527.97 ha or $3.39 \%$ (Figure 11 ).

The increase of the natural landscape of Lithuania was impacted by the progress of the forest area (6.15\%).

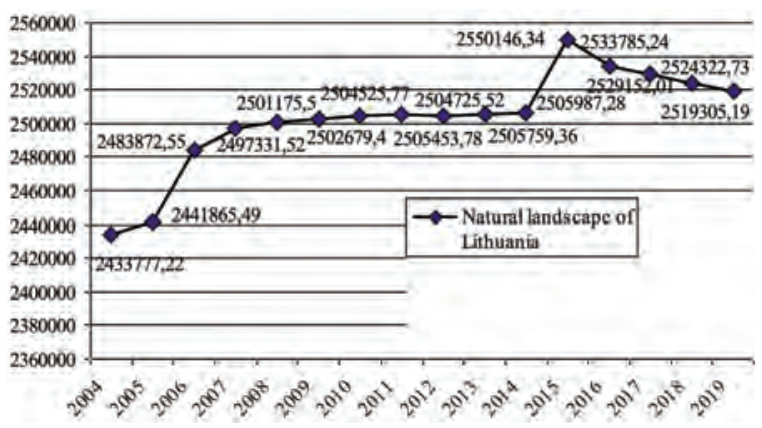

Figure 11. Natural landscape change in Lithuania in 2004-2019 (Nacionaline, 2004-2019).

We need to save and protect natural resources and this important movement includes forests, water, land, and biological species.

The natural landscapes are essential for clean water, healthy ecosystems, climate resilience, cultural heritage, outdoor recreation, and local sense of place. Benefits like improved water quality, increase in biodiversity and habitat protection, and reductions in greenhouse gases, are all inherent in the strategy that protects and preserves land.

\section{Conclusions}

1. Lithuania is dominated by rustic landscape (75\% of Lithuania). Larger areas of the natural landscape are preserved in the eastern and southeastern parts of the country, in the western part of the Samogitian Heights, in the areas of the great deltas and do not exceed $15 \%$ of the territory of Lithuania. About $10 \%$ of the territory is occupied by a rapidly expanding urban, urbanized landscape.

2. Between 2004-2019 the forest area of the country increased by $132,849.03$ ha (6.15\%).

3. During the years 2004-2019, the area of water bodies enlarged by 3,668.49 ha (1.38\%) and by 2019 occupied 265,868.26 ha.

4. The area of wetlands in 2004-2019 decreased by $50,990.20$ ha $(35.05 \%)$ and in 2019 covered $94,487.25$ ha.

5. In 2004-2019, the natural landscape of Lithuania increased by 85527.97 ha or 3.39\%. The increase of the natural landscape of Lithuania was impacted by the progress of the forest area.

\section{References}

Antrop, M. (2000). Geography and landscape science. Belgeo. 1(2): 9-36. DOI: 10.4000/belgeo.13975.

Aplinkos apsaugos agentūra. (2019). Lietuvos Respublikos upių, ežerų ir tvenkinių kadastras. (The Environmental Protection Agency. Cadastre of Rivers, Lakes and Ponds of the Republic of Lithuania). 
Retrieved January 15, 2020, from http://vanduo.gamta.lt/cms/index?rubricId=7cdeb451-1844-4e9d-af55af1be4215e83. (in Lithuanian).

Basalykas, A. (2014). Lietuvos kraštovaizdis. (The Lithuanian Landscape). Vilnius, 243 p. (in Lithuanian).

Galan-Acedo, C., Arroyo-Rodriguez, V., Andresen, E., Arregoitia, L.V., Vega, E., Peres, C.A., \& Ewers, R.M. (2019). The conservation value of human-modified landscapes for the world's primates. Nature Communications. 10, Article No. 152.

Ivaviciute, G. (2018). The Change of Forest and Its Area in Lithuania // Research for rural development 2018: annual $24^{\text {rd }}$ international scientific conference proceedings / Latvia University of Agriculture. Jelgava. ISSN 1691-4031. Vol. 1, pp. 174-180.

Lietuvos Respublikos Vyriausybès nutarimas. Dèl Lietuvos Respublikos kraštovaizdžio politikos krypčių aprašo patvirtinimo. (Resolution of the Government of the Republic of Lithuania. On Approving the Description of the Landscape Policies of the Republic of Lithuania). (2004 12 01, No. 1526. From the State News: 2004, No. 174-6443; valid summary 201401 31). (in Lithuanian).

Mayer, A., Buma, B., Davis, A, Gagne, S.A., Loudermilk, L., Scheller, R.M., Schmiegelow, F.K.A., Wiersma, Y.F., \& Franklin, J. (2016). How Landscape Ecology Informs Global Land-Change Science and Policy. BioScience. Vol. 66, Issue 6, pp. 458-469. DOI: 10.1093/biosci/biw035.

Musacchio, L.R. (2011). The grand Challenge to operationalize landscape sustainability and the design-inscience paradigm. Landscape Ecology. 26, 1-5.

Nacionalinè žemès tarnyba prie Žemès ūkio ministerijos. (2004-2019). Lietuvos Respublikos žemés fondas. (The National Land Service under the Ministry of Agriculture. Land Fund of the Republic of Lithuania). Vilnius. 2004-2019, 144 p. (in Lithuanian).

Opdam, P., Luque, S., Nassauer, J., Verburg, P.H., \& Wu, J. (2018). How can landscape ecology contribute to sustainability science? Landscape Ecology. 33, 1-7.

Parrott, L., \& Meyer, W.S. (2012). Future landscapes: managing within complexity. Frontiers in Ecology and the Environment. DOI: 10.1890/110082.

Raymond, CH.M., \& Cleary, J. (2013). A Tool and Process that Facilitate Community Capacity Building and Social Learning for Natural Resource Management. Ecology and Society. 18 (1), 25. DOI: 10.5751/ES05238-180125.

Robinson, G.M., \& Carson, D.A. (2013). Applying landscape science to natural resource management. Ecology and Society 18 (1), 32. DOI: 10.5751/ES-05639-180132.

Steiner, F. (2011). Landscape ecological urbanism: Origins and trajectories. Landscape and Urban Planning. Vol. 100, Issue 4. pp. 333-337.

Tscharntke, T., Tylianakis, J.M., Rand, T.A., Didham, R.K., Fharing, L., Batary, P., Bengtsson, J., Clough, Y., Crist., T.O., Dormann, C.F., Ewers, R.M., Frund, J., Holt, R.D., Holzschuh, A., Klein, A.M., Kleijn, D., Kremen, C., Landis, D.A., Laurance, W., Lindenmayer, D., Scherber, Ch., Sodhi, N., Steffan-Dewenter, I., Thies, C., van der Putten, W.H., \& Westphal, C. (2012). Landscape moderation of biodiversity patterns and processes - eight hypotheses. Biological Reviews. DOI: 10.1111/j.1469-185X.2011.00216.x.

Turner II, B.L., Lambin, E.F., \& Reenberg, A. (2007). The emergence of land change science for global environmental change and sustainability. PNAS. 104 (52). pp. 20666-20671. DOI: 10.1073/ pnas.0704119104. 